\title{
DENDROCLIMATOLOGY IN THE EASTERN MEDITERRANEAN
}

\author{
RAMZI TOUCHAN ${ }^{1 *}$, DAVID M. MEKO ${ }^{1}$, and KEVIN J. ANCHUKAITIS ${ }^{2}$
}

${ }^{1}$ Laboratory of Tree-Ring Research, The University of Arizona, 1215 E. Lowell St., Bldg. 45B, Tucson, Arizona 85721, USA.

${ }^{2}$ Woods Hole Oceanographic Institution, Department of Geology and Geophysics, 121A Clark Laboratory, 266 Woods Hole Rd. MS \#23, Woods Hole, MA 02543, USA.

*Corresponding author: rtouchan@1trrarizona.edu.

\begin{abstract}
Dendroclimatology in the Eastern Mediterranean (EM) region has made important contributions to the understanding of climate variability on timescales of decades to centuries. These contributions, beginning in the mid-20th century, have value for resource management, archaeology, and climatology. A gradually expanding treering network developed by the first author over the past 15 years has been the framework for some of the most important recent advances in EM dendroclimatology. The network, now consisting of 79 sites, has been widely applied in large-scale climatic reconstruction and in helping to identify drivers of climatic variation on regional to global spatial scales. This article reviews EM dendroclimatology and highlights contributions on the national and international scale.
\end{abstract}

Keywords: dendroclimatology, Eastern Mediterranean, tree-ring growth, reconstruction, drought.

\section{INTRODUCTION}

Dendroclimatology is the study of the relationship between treering growth and climate variability and the use of that relationship to reveal patterns of climate variation in the past. Indirect evidence of climatic variability is gleaned from proxy records of past conditions, such as pollen, speleothems, lacustrine sediments, ice cores, historical documentations, and long time series of replicated tree-ring growth measurements spanning several centuries. One advantage of tree-ring records is their precise dating to the exact calendar year, which allows them to be compared directly with instrumental records. This provides a powerful tool for developing quantitative reconstructions of climate on seasonal to century or longer timescales that include estimates of uncertainty. They also represent the most geographically widespread proxy records capable of yielding annually resolved time series over the last millennium (e.g. Touchan et al. 2003; Jones and Mann 2004; Briffa et al. 2004; Esper et al. 2004) and generally possess the highest correlations with instrumental climate data (Jones et al. 1998).

The following three sections describe the chronological development of dendroclimatology in the Eastern Mediterranean (EM). This development can conveniently be organized into studies documenting the climate signal in tree rings, climate reconstructions on the local and small-regional scale, and climate reconstructions on the large scale from extensive spatial networks of tree-ring chronologies. Two concluding sections address the relevance of tree-ring studies to climatology of the EM, and discuss tree-ring network expansion with a view to the future.

\section{INTERACTION BETWEEN TREE-RING CHRONOLOGIES AND CLIMATE}

Dendroclimatology in the EM was in its infancy until the late 20th century. The first dendroclimatological attempt in the region was by Gassner and Christiansen-Weniger (1942), who demonstrated that tree growth in parts of northeastern Turkey is significantly influenced by precipitation. Gindel (1944) investigated the relationship between Pinus helepenis and precipitation and temperature in the Judean Hills/Jibal al-Khalil in Israel and the West Bank. This work was followed some decades later by a number of diagnostic dendroclimatic studies in various parts of the EM (Liphschitz and Waisel 1967; Shanan et al. 1967; Waisel and Liphschitz 1968; Lev-Yadun et al. 1981; Chalabi and SerreBachet 1981; Munaut 1982; Parsapajouh et al. 1986; Chalabi and Martini 1989; Akkemik 2000, 2003; Hughes et al. 2001; Köse and Güner 2012).

Touchan and Hughes (1999) were able to build the first set of EM tree-ring chronologies with a dendroclimatological focus. Chronologies from Pinus halepensis and Quercus aegilops in Jordan and from $P$. halepensis on Mt. Carmel in Israel were analyzed for the spatial coherence of their ring width variations. Significant correlation was found between the northern site chronologies (northern Jordan and northwestern Israel), but not between chronologies in northern and southern Jordan.

In Turkey, Akkemik (2000) investigated the response of a Pinus pinea tree-ring chronology from near Istanbul to climate variables, and reported important influence from both temperature and precipitation. A positive influence of precipitation was found for all months except March and June, while the significant influence of temperature was positive but limited to March and April. Hughes et al. (2001), working with living tree chronologies developed by Peter Kuniholm, demonstrated that crossdating over large distances in Greece and Turkey has a clear climatological basis, with signature years consistently associated with specific persistent atmospheric circulation anomalies.

Center for Mediterranean Archaeology and the Environment (CMATE) Special Issue

Joint publication of Radiocarbon and Tree-Ring Research 


\section{LOCAL-SCALE DENDROCLIMATOLOGICAL RECONSTRUCTIONS}

The aforementioned studies laid the groundwork for the building of an EM tree-ring network specifically aimed at improved understanding of local and regional climatology of the EM. Several local-scale dendroclimatological reconstructions were developed in different parts of the EM in the late 1990s and early 2000s. For example, Touchan et al. (1999) developed the first dendroclimatic reconstruction in the Near East in the form of a 396-year-long estimated record of October-May precipitation in southern Jordan from two chronologies of Juniperus phoenicia. The longest reconstructed drought, as defined by consecutive years below $80 \%$ of the 1946-1995 mean observed October-May precipitation, lasted 4 years. In comparison, the longest drought recorded in the 1946-1995 instrumental data lasted only 3 years.

D'Arrigo and Cullen (2001) soon followed with the first precipitation reconstruction for central Turkey (Sivas). The reconstruction of February-August precipitation covered 350 years, but gave only a limited perspective on the climate variation during the last few decades because the chronologies used had been collected much earlier - in the 1980s by Peter Kuniholm. Their reconstruction of wet and dry intervals indicated that no drought, as measured by precipitation more than one standard deviation below the mean, lasted for more than two consecutive years.

Touchan and Hughes, with support from the U.S. National Science Foundation, set out to develop an extensive regional network of EM chronologies specifically as proxy records of climate (Figure 1). The first part of this effort yielded 36 chronologies from 42 sites; the well-replicated tree-ring chronologies with high sample depth (at least 20 trees per site) provided tree-ring coverage back to AD 1017. Touchan et al. (2003) used tree-ring data from living and dead trees in southwestern Turkey to reconstruct spring (May-June) precipitation several centuries back in time. Their reconstructions show clear evidence of multiyear to decadal variations in spring precipitation. Within those variations, the longest period of spring drought was 4 years (1476-1479). Only one drought event of this duration has occurred during the last

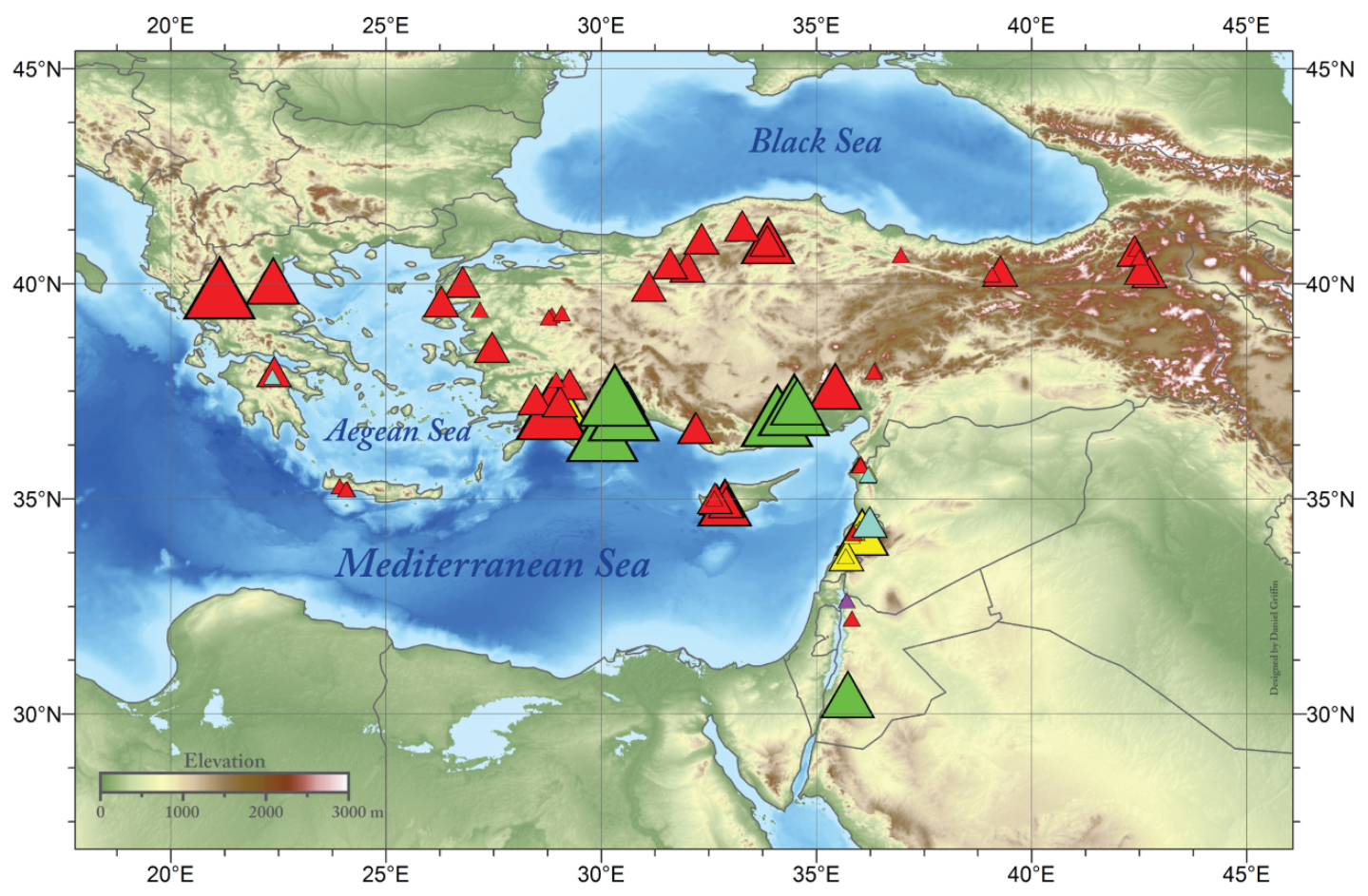

TREe-RING CHRONOLOGIES

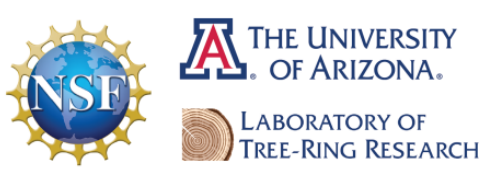

Funded by the National Science Foundation Award \#0075956 and Award \#0758486
Genus

$\triangle$ Abies

$\triangle$ Cedrus

$\triangle$ Juniperus

$\triangle$ Pinus

$\triangle$ Quercus
Length

$\Delta<250 \mathrm{yr}$

$\triangle 251-500 \mathrm{yr}$

501-750 yr

751-970 yr

Figure 1. Locations of tree-ring chronology sites. 
6 centuries. Monte Carlo analysis designed to take into account the uncertainty in the tree-ring reconstruction indicated a less than $33 \%$ probability that southwestern Turkey has experienced spring drought longer than 5 years in the past 660 years. The longest reconstructed wet periods were found during the 16th and 17th centuries. Touchan et al. (2003) also found that spring drought (wetness) is connected with warm (cool) conditions and southwesterly (continental) circulation over the EM.

A major dendroclimatological advance in the EM was the first reconstruction there of a drought index (Touchan et al. 2005a). The reconstruction covers most of Turkey and some adjoining regions for the period AD 1251-1998 and uses as a drought measure the standardized precipitation index (SPI), a widely accepted moisture index that provides an objective method for determining drought conditions at multiple timescales (Edwards and McKee 1997). This first SPI reconstruction provided important regional information concerning hydroclimatic variability in southwestern and south-central Turkey.

Small-scale reconstructions in the EM have taken advantage of multiple tree species. Pinus nigra tree rings were used by Akkemik and Aras (2005) to reconstruct April-August precipitation (1689-1994) for the southern part of central Turkey. Oak tree rings were used by Akkemik et al. (2005) to develop a MarchJune precipitation reconstruction for the western Black Sea region of Turkey. They found that during the past 4 centuries drought events in this region persisted for no more than 2 years, and that single-year extreme dry and wet events have occurred frequently. These various tree-ring studies in Turkey suggest that runs of dry years rarely last for more than 3 years. Griggs et al. (2014) developed a September-August precipitation and drought reconstruction for AD 1830-2006 from Pinus brutia tree rings for Cyprus. This study, making use of trees from low and medium elevations, provides the first long-term assessment of annual precipitation and drought for Cyprus, and emphasizes the importance of elevation for the seasonality of the climate signal embedded in tree rings.

Using tree-ring data from living-tree and archaeological samples, Akkemik et al. (2008) developed the first precipitation and streamflow reconstruction for northwestern Turkey. The streamflow reconstruction was for the Filyos River, near the western Black Sea. High-frequency variations were found to be especially important, accounting for $34 \%$ of the variance of May-June precipitation and $53 \%$ of the variance of May-August streamflow. They reported that $90 \%$ of actual flood events were observed in the streamflow reconstruction.

Tree-ring variables other than ring width have also proved useful in the EM, although the number of applications is still small. Heinrich et al. (2013) developed the first winter-spring temperature reconstruction in the EM from a centuries-long Juniperus excelsa chronology of stable isotopic ratios of carbon. This reconstruction, from Turkey, demonstrated that variability of $\delta^{13} \mathrm{C}$ in tree rings of $J$. excelsa is dependent on January-May tempera- tures. Low-frequency trends that were associated with the Medieval Climate Anomaly and the Little Ice Age were identified in this temperature reconstruction. However, the 20th century warming trend seen in other parts of the world could not be identified in their reconstruction. The lack of this feature is not surprising, as it also was absent from the regional meteorological data used in their study. Mutlu et al. (2012) conducted oxygen and carbon isotopic analyses on tree rings collected at two different elevations from three different regions in western Anatolia, Turkey. They reported that $\delta^{13} \mathrm{C}$ ratios have mostly positive responses to temperature and precipitation variations, whereas $\delta^{18} \mathrm{O}$ and summer temperature/ precipitation are negatively correlated. Tree-ring widths and $\delta^{18} \mathrm{O}$ values display similar responses to temperature and sensitivity to the climatic impact of historic volcanic eruptions.

\section{REGIONAL DENDROCLIMATIC RECONSTRUCTIONS}

Touchan et al. (2005b) developed the first regional MayAugust precipitation reconstruction for the EM (Turkey, Syria, Lebanon, Cyprus, and Greece) and investigated the relationship of the reconstruction to large-scale atmospheric circulation. Six separate May-August precipitation reconstructions ranging in length from 115 to 600 years were reported in this work. Although general circulation models do predict imminent drying in the Mediterranean caused by anthropogenic greenhouse gas emissions (Christensen et al. 2007), no long-term trends were seen over the last several centuries in either drought amplitude or frequency. Large-scale atmospheric circulation influences on regional May-August precipitation were identified over the EM region. For example, precipitation in this season is driven by anomalous below (above) normal pressure at all atmospheric levels and by convection (subsidence) and small pressure gradients at sea level.

Griggs et al. (2007) developed a regional May-June precipitation reconstruction from oak tree rings from a number of locations in Greece and Turkey for the period AD 1089-1989. They investigated various methods of manipulating tree-ring data for their regional climatic reconstruction and concluded that removing all but the high-frequency variability plus normalizing the oak data sets before combining them into a master chronology were optimal techniques for a reasonable precipitation reconstruction of the entire area over the instrumental period. They discovered that these methods not only removed the low-frequency signal but also diminished some evidence of local extremes in their reconstruction.

Köse et al. (2011) developed the first spatial May-June precipitation reconstruction using 17 Pinus nigra chronologies from western Anatolia and examined past dry and wet events. They observed that the long-term local May-June precipitation reconstructions contain mostly 1-year and, less commonly, 2-year drought events.

The first author has continued his systematic dendroclimatic sampling in the EM region and updated and added 48 chronologies from the region, making a total of 79 chronologies (Figure 1). 
Touchan et al. (2014) described and analyzed this network in the EM $\left(33-42^{\circ} \mathrm{N}, 21-43^{\circ} \mathrm{E}\right)$ to identify the seasonal climatic signal in indices of annual ring width. Correlation analysis and cluster analysis were applied to tree-ring data and gridded climate data to assess the climate signal embedded in the network in preparation for climate field reconstructions and formal proxy/model intercomparison experiments. Monthly correlations and partial correlations revealed a pervasive positive association of tree growth with May, June, and sometimes July precipitation, positive correlations with winter and spring (December through April) temperatures, and negative relationships with May through July temperature. Cluster analysis suggested distinct groups of sites based on the association of tree-ring chronologies with climate. The analysis showed that chronologies for the EM have coherent seasonal precipitation and temperature signals across a fairly broad geographical domain, and that the predominant signal is a positive growth response to May-June precipitation. Some elevational dependence was also noted in the clusters of tree-ring sites identified according to similarity of seasonal climate response. The Touchan et al. (2014) results are also consistent with the findings of Griggs et al. (2014) on the importance of elevation of tree-ring sites to dendroclimatic interpretation in Cypress.

\section{DENDROCLIMATOLOGY AND ATMOSPHERIC CIRCULATION}

The climate of the EM domain is influenced by a variety of local and remote features of atmosphere-ocean circulation. Eshel and Farrell (2000) showed that winter precipitation anomalies in the Mediterranean were linked to the large-scale North Atlantic circulation through opposite sign pressure anomalies over Greenland and the Adriatic. Low pressure over Greenland is linked to higher pressure over Europe and the Mediterranean, anomalous northeasterly winds and enhanced subsidence over the EM, and reduced winter precipitation. Alternatively, high pressure over the North Atlantic and low pressure over the Mediterranean and southern Europe lead to southwesterly wind anomalies, a warming of the EM, and enhanced rainfall. These spatial patterns are similar to, although distinguishable from, those typically associated with the winter NAO (Eshel and Farrell 2000). At the regional scale over the EM, observed winter rainfall in Turkey is negatively correlated with the concurrent winter NAO index, while south of ca. $33^{\circ} \mathrm{N}$ the sign of the winter precipitation-NAO correlation is positive through Israel, Jordan, and Egypt. The El Niño Southern Oscillation (ENSO) may also leave an imprint in the climate of the region, although the sign of the influence changes from season to season, across the spatial domain, and may be temporally unstable (Mariotti et al. 2002).

Application of EM tree-ring chronologies to reconstruction of the NAO or ENSO is, however, complicated by the dominant May-June precipitation signal seen across the regional proxy network (Touchan et al. 2014). Figure 2 shows the correlation between May-June mean precipitation and the concurrent NINO3.4 and NAO indices. The patterns revealed are weak, largely insig- nificant correlations without a discernable coherent spatial pattern. This lack of a clear and stable association between these large-scale circulation features and the primary local control on regional tree growth makes it difficult to develop robust inferences about these modes from these chronologies alone. Touchan et al. (2003) likewise observed that correlations between spring NAO and instrumental May-June precipitation in Turkey were largely weak and nonsignificant, and they were cautious in interrupting similarly low, lagged correlations between instrumental and reconstructed precipitation and the winter NAO. Griggs et al. (2007) developed a reconstruction of the May NAO, but also discussed the relatively weak ( $r=-0.27$ to 0.22 ), marginally significant, and unstable associations between their North Aegean oak tree-ring chronology and the April and May NAO index. However, Griggs et al. (2014) also reported that multiyear drought periods in their September through August Cyprus precipitation reconstruction were related to the combined impact of the NAO and East Atlantic/West Russia Pattern (EAWR). They suggested that a positive NAO and a positive EAWR combined to cause drought. Variability in the association between large-scale modes like ENSO and NAO and EM climate, as well as the interactions between remote and local climate modes, in the spring and summer presents a significant challenge for developing tree-ring reconstructions of remote teleconnections from the region.

While the association with remote large-scale modes of climate variability may be equivocal, tree-ring growth anomalies, reflecting precipitation and hydroclimate variability in the region, are indeed linked to circulation anomalies. Touchan et al. (2005b) showed that anomalous May-August precipitation and tree growth in the EM was linked to anomalous surface pressure and geopotential height patterns across the southern North Atlantic, Mediterranean, and Asia. Reduced spring-summer precipitation is related to regional subsidence and greater vertical stability, with the driest tree-ring reconstructed years associated with positive sea-level pressure anomalies over the Mediterranean. Touchan et al. (2005b) concluded that their reconstructed climatic conditions reflected regional as well as local and topographical influences on precipitation.

Tree-ring chronologies in the EM certainly reflect the influence of regional and local circulation anomalies; however, the spring-summer climatic response in these chronologies indicates that the relationship between large-scale modes of climate variability and tree growth is very likely unstable through time and it would be difficult to confidently separate combined or competing remote influences, particularly prior to the instrumental era. Climate field reconstructions may, however, provide the spatiotemporal information necessary to identify "fingerprints" of the myriad climate influences on this region.

Touchan et al. (2005b) demonstrated the utility of comparing tree-ring-derived data and independent reconstructions of largescale sea-level pressure (SLP) and surface air temperature based on primarily documentary evidence including specific informa- 


\section{MJ PRECIPITATION VS NINO3.4}

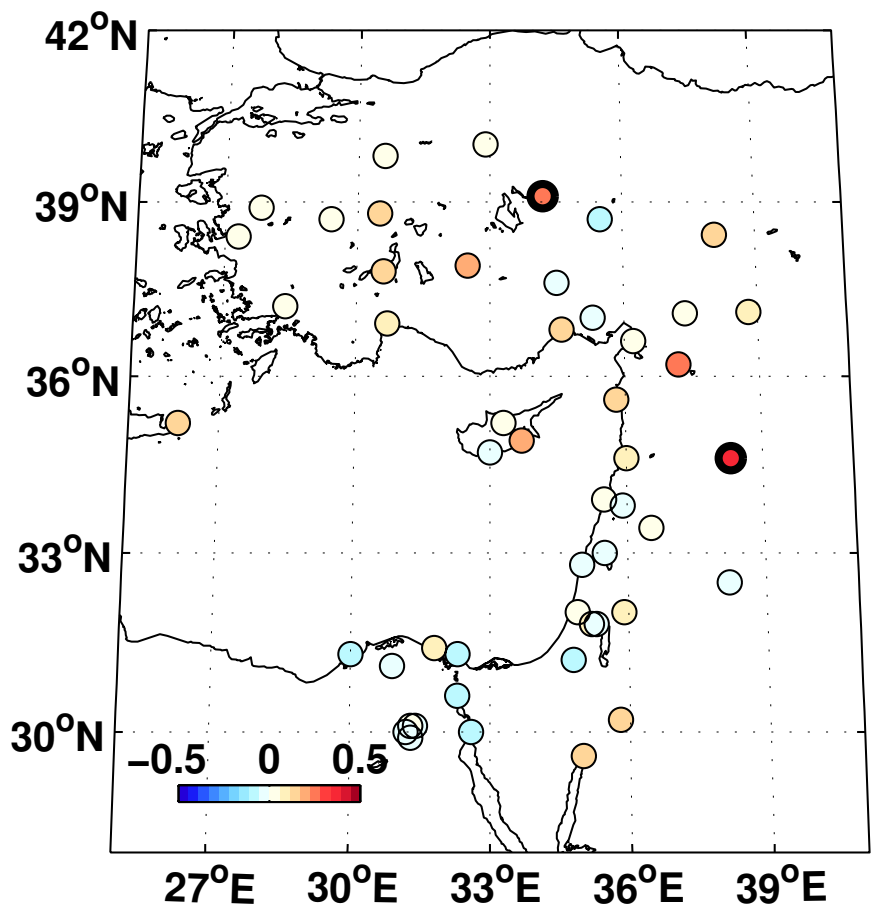

MJ PRECIPITATION VS NAO

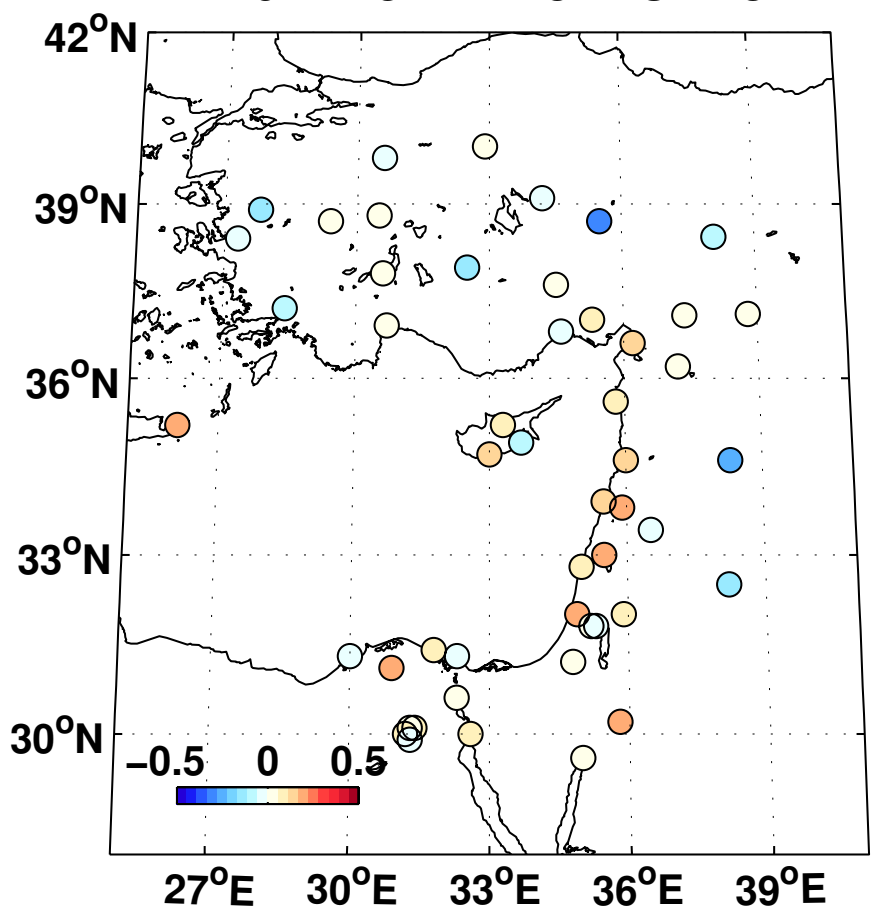

Figure 2. Correlation between Eastern Mediterranean instrumental May-June precipitation records from the Global Historical Climate Network (GHCN, Peterson and Vose 1997) with at least 50 years of available data and the concurrent NINO3.4 (left) and NAO (right) indices. Significant values $(\mathrm{p}<0.05)$ are indicated by dark outline circles.

tion on weather elements (e.g. number of rainy days, direction of cloud movement, wind direction, warm and cold spells, freezing of water bodies, droughts, floods, information on vegetation). They showed that large-scale climatic patterns associated with precipitation and tree-ring growth in this region have been substantially stable for the last 237 years (Touchan et al. 2005b). This helps to validate both sources of information on past climate, and also suggests that the reconstructions are physical valid.

Heinrich et al. (2013) reported a north-south contrast in recent temperature trends from analysis of their $\delta^{13} \mathrm{C}$-based winter-spring temperature reconstruction. Comparison of the reconstruction with other Northern Hemisphere temperature proxy showed similar low-frequency variations until the beginning of the 20th century, but divergence afterward. The more recent part of the record indicates warming north of the EM but not in Turkey. Heinrich et al. (2013) also discovered from correlation analyses of their reconstruction with several climate indices that various atmospheric oscillation patterns may influence the temperature variations in southwestern Turkey.

Investigations often link dendroclimatic reconstructions to other proxy records of past climate, as well as historical documents (D'Arrigo and Cullen 2001; Akkemik et al. 2005, 2008; Touchan et al. 2005a, 2005b, 2007; Griggs et al. 2007; Köse et al. 2011). For example, all these studies identify the year AD 1660 as a dry summer-a finding consistent with Purgstall's (1983) reporting of catastrophic fires and famine in Anatolia in the same year. A 70-year moving average of an AD 1097-2000 reconstruction of May-June precipitation by Touchan et al. (2007) for southwestern Anatolia in Turkey revealed AD 1518-1587 is the most humid multidecadal period. Pfister et al. (1999) reported that the 16th century marks a significant shift in the climate in Europe to a period of generally cooler conditions that had profound effects on environment and society. Touchan et al. (2007) also indicated that the period AD 1591-1660 represents the second driest interval in their reconstruction, corresponding with the findings of Kuniholm (1990) and Griswold (1977, 1983, 1989). These last authors reported that the late 16 th and early 17 th centuries in Anatolia were characterized by political, social, and climatic instability, which caused a large-scale change in land use and large sudden fluctuations in urban populations. White (2011) has also linked various Little Ice Age sociopolitical crises in the Ottoman Empire to tree-ring-reconstructed drought.

\section{NETWORK EXPANSION AND RESEARCH DIRECTIONS}

Dendroclimatology in the EM has already been shown to be capable of contributing to the understanding of drivers of climatic variation on regional to hemispherical spatial scales (e.g. Touchan et al. 2008). The large-scale climatic signal in tree rings is supported by the synchrony in occurrence of narrow rings or wide rings over large distances. This synchrony essentially represents the cross-datability of tree-ring chronologies over large regions, and reflects the climatic imprint on ring widths. The instrumental record of climatic data can be exploited to associate particular 
spatial patterns of atmospheric circulation anomaly with signature years in which trees over large regions have common ring-width anomalies. The longer-term tree-ring record can then be examined for earlier instances of such anomalies, and the annual resolution of tree-ring data can be exploited to estimate frequency of occurrence of atmospheric anomaly patterns over past centuries.

A minimum requirement for such application is a widely distributed network of climate-sensitive tree-ring chronologies overlapping the period of instrumental data. The network mapped in Figure 1 is only a start toward this objective. For optimum value, these chronologies, or some subset of them, should have a common climatic signal for some season of climatological interest. For example, chronologies with a signal for cool-season precipitation in the EM could be evaluated for evidence of major northsouth shifts in storm track and the influence of the NAO. Such an application is all the more possible if networks of chronologies with a similar seasonal climatic sensitivity are also available from neighboring regions (e.g. central and southern Europe). These data can be examined probabilistically for the likelihood of future or past parallel shifts in atmospheric anomaly. The data can also be applied in conjunction with output of general circulation models (GCMs) to assess the ability of these models to represent climatic variability on long timescales (e.g. Touchan et al. 2011).

Extension of tree-ring reconstructions from the time range of a few centuries to many centuries and millennia in the EM is an intriguing challenge to dendroclimatology. The distant past (e.g. the Medieval period) is of great interest climatologically both for the evidence of great climatic fluctuations in other regions, and for the estimated large-amplitude variation in some forcing factors, particularly climatically effective volcanic eruptions. The limited age span of EM trees compared with that of trees in some other parts of the world means that temporal extension of reconstruction to many hundreds of years or to thousands of years requires the use of preserved remnant wood (stumps, logs, snags) and archaeological wood. Because of human pressures, remnant wood is rapidly disappearing from the EM landscape. Archaeological wood presents some climatological hurdles, as the provenance and the local hydrological setting of the samples may be unknown, and the sample depth and spatial coverage of the ancient tree-ring network is unlikely to approach that of the network of living-tree chronologies from the most recent centuries. But if ecological conditions of tree growth of the ancient material can be reasonably assumed to resemble those of the living trees, it may be possible to glean useful information on interannual to multidecadal variability in the distant past as was demonstrated by Griggs et al. (2007).

Ideally, remnant-wood samples overlap living-tree samples, such that an exact calendar year can be assigned to each year of the remnant-wood samples. Some useful climatic inferences may be possible, however, even if the remnant-wood tree-ring records are "floating" (cf. Kuniholm et al. 1996), or not anchored to a known calendar year, as long as they are strongly dated against one another. For example, it might be possible to examine a network of floating chronologies for evidence of a general change in spectrum, or relative importance of high- to low-frequency variation between some distant time and the present. For example, Bannister (1970) collected and analyzed tree-ring specimens from an 8th century BC tomb in Gordion, Turkey, and carried out preliminary examination of wood samples from Egyptian coffins and pyramids and collected and crossdated samples of Cedar of Lebanon (Cedrus libani) in Lebanon. Bannister laid out the necessary conditions for the successful application of the methods of archaeological dendrochronology in this region. Several other studies followed the lead of Bannister in the region, such as Kuniholm and Striker (1987), Kuniholm (1990, 1994, 2000), and Pearson et al. (2012).

The past climate matters of course for more than just an abstract appreciation of the temporal instability of climate statistics or the identification of strengths and weaknesses of GCMs. Human behavior is guided by knowledge and perceptions of past climate. For example, the perception that it has never rained in June or July is likely to steer people away from dryland farming of summer crops. On timescales of many centuries, it is possible to identify periods, long in comparison with human generations, when climate has differed markedly from that we experience today. The long-term climate record from tree rings can accordingly contribute to archaeology by giving insight into climate conditions associated with changes in past societies, and to modern society in pointing out vulnerability of water supplies and agriculture to episodic changes in regional climate.

Dendroclimatological research efforts in the region have made and will continue to make significant contributions on the national and international scale. Nationally, findings can be important in providing a decadal to multicentury perspective on climate variability to local managers of land and water resources. Given the significance and strategic importance of water in the EM, this perspective could have considerable impact on water resource policy and management by countries in the region, and on political agreements between countries. The Mediterranean is a region of water deficit with a history of conflict over land and natural resources. The information in tree-ring reconstructions will aid in anticipating, and, it is hoped, in lessening the likelihood of conflict over scarce water resources, as well as contributing to the physically sound interpretation of evidence of climate variability and its social consequences in past times.

\section{ACKNOWLEDGMENTS}

Funding was provided by the US National Science Foundation (NSF) under grants from the Earth System History (ESH) and Paleo Perspectives on Climate Change (P2C2) programs, AGS0075956, AGS-0758486, and AGS-1103314. We thank Malcolm K. Hughes for his helpful suggestions on the manuscript. Dan Griffin created Figure 1. 


\section{REFERENCES}

Akkemik, Ü., 2000. Dendroclimatology of umbrella pine (Pinus pinea L.) in Istanbul, Turkey. Tree-Ring Bulletin 56:17-23.

Akkemik, Ü., 2003. Tree-rings of Cedrus libani at the northern boundary of its natural distribution. IAWA Journal 24(1):63-73.

Akkemik, Ü., and A. Aras, 2005. Reconstruction (1689-1994 AD) of AprilAugust precipitation in the southern part of central Turkey. International Journal of Climatology 25(4):537-548.

Akkemik, Ü., N. Dağdeviren, and A. Aras, 2005. A preliminary reconstruction (A.D. 1635-2000) of spring precipitation using oak tree rings in the western Black Sea region of Turkey. International Journal of Biometeorology 49(5):297-302.

Akkemik, Ü., R. D'Arrigo R, P. Cherubini, N. Köse, and G. C. Jacoby, 2008. Treering reconstructions of precipitation and streamflow for north-western Turkey. International Journal of Climatology 28(2):173-183.

Bannister, B., 1970. Dendrochronology in the Near East: Current research and future potentialities. In Proceedings of the Seventh International Congress of Anthropological and Ethnological Sciences, Moscow, 1964, 5:336-340.

Briffa, K. R., T. J. Osborn, F. H. Schweingruber, 2004. Large-scale temperature inferences from tree rings: A review. Global and Planetary Change 40(12):11-26.

Chalabi, M. N., and G. Martini, 1989. Etude dendroclimatologique de l'Abies cilicica (Ant. et Ky) de Syre. Research Journal of Aleppo University 12:57-89.

Chalabi, M. N., and F. Serre-Bachet, 1981. Analyse dendroclimatologique de deux stations syriennes de Quercus cerris ssp pseudocerris. Ecologia Mediteranea $7: 3-21$.

Christensen, J., B. Hewitson, A. Busuioc, A. Chen, X. Gao, I. Held, P. D. Jones, R. K. Kolli, W. T. Kwon, R. Laprise, V. Magana, L. Mearns, C. G. Menendez, J. Raisanen, A. Rinke, A. Sarr, and P. Whetton, 2007. Regional climate projections. In Climate Change 2007: The Physical Science Basis. Contribution of Working Group I to the Fourth Assessment Report of the Intergovernmental Panel on Climate Change, edited by S. Solomon, D. Qin, M. Manning, Z. Chen, M. Marquis, K. B. Averyt, M. Tignor, and H. L. Miller; pp. 849-926. Cambridge University Press, Cambridge.

D'Arrigo, R. D., and H. M. Cullen, 2001. A 350-year (AD 1628-1980) reconstruction of Turkish precipitation. Dendrochronologia 19:169-177.

Edwards, E. C., and T. B. McKee, 1997. Characteristics of 20th century drought in the United States at multiple time scales. Paper No. 634, Climatology Report No. 97-2, Colorado State University, Fort Collins, Colorado.

Eshel, G., and B. F. Farrell, 2000. Mechanisms of Eastern Mediterranean rainfall variability. Journal of the Atmospheric Sciences 57(19):3219-3232.

Esper, J., D. C. Frank, and R. J. S. Wilson, 2004. Climate reconstructions: Low-frequency ambition and high-frequency ratification. Eos, Transactions: American Geophysical Union 85(12):113-120.

Gassner, G., and F. Christiansen-Weniger, 1942. Dendroklimatologische Untersuchungen über die Jahresringentwicklung der Kiefern in Anatolien. Nova Acta Leopoldina. Abhandlung der Kaiserlich Leopoldinisch-Carolinisch deutschen Akademie der Naturforscher NF, Band 12, Nr 80.

Gindel, J., 1944. Aleppo pine as medium for tree-ring analysis. Tree-Ring Bulletin 11(1):6-8.

Griggs, C., A. DeGaetano, P. Kuniholm, and M. Newton, 2007. A regional high-frequency reconstruction of May-June precipitation in the north Aegean from oak tree rings, A.D. 1089-1989. International Journal of Climatology 27(8):1075-1089.

Griggs, C., C. Pearson, S. W. Manning, and B. Lorentzen, 2014. A 250-year annual precipitation reconstruction and drought assessment for Cyprus from Pinus brutia Ten. tree-rings. International Journal of Climatology 34(8):2702-2714.

Griswold, W. J., 1977. The Little Ice Age: Its effect on Ottoman history, 15851625. Paper presented at the Middle East Studies Association Meeting, New York.

Griswold, W. J., 1983. The Great Anatolian Rebellion 1000-1020/1591-1611. Klaus Schwartz Verlag, Berlin.

Griswold, W. J., 1989. Climatic Change: A Possible Factor in Social Unrest of Seventeenth Century Anatolia. Studies in Honor of Andreas Tietze. Divit Press, Istanbul.

Heinrich, I., R. Touchan, I. D. Liñán, H. Vos, and G. Helle, 2013. Winter-to-spring temperature dynamics in Turkey derived from tree rings since AD 1125. Jour- nal of Climate Dynamics 41(7-8):1685-1701.

Hughes, M. K., P. I. Kuniholm, J. Eischeid, G. M. Garfin, C. Griggs, and C. Latini, 2001. Aegean tree-ring signature years explained. Tree-Ring Research 57(1):67-73.

Jones P. D., and M. E. Mann, 2004. Climate over past millennia. Reviews of Geophysics 42:RG2002, doi:10.1029/2003RG000143.

Jones, P. D., K. R. Briffa, T. Barnett, and S. Tett, 1998. High resolution paleoclimatic records for the last millennium: Interpretation, integration and comparison with General Circulation Model control-run temperature. The Holocene 8(4):455-471.

Köse, N., and H. T. Güner, 2012. The effect of temperature and precipitation on the intra-annual radial growth of Fagus orientalis Lipsky in Artvin, Turkey. Turkish Journal of Agriculture and Forestry 36(4):501-509.

Köse, N., Ü. Akkemik, H. N. Dalfes, and M. S. Özeren, 2011. Tree-ring reconstructions of May-June precipitation for western Anatolia. Quaternary Research 75(3):438-450.

Kuniholm, P. I., 1990. The archaeological record: Evidence and non-evidence for climate change. In Runcorn SK, Livezey RE, Smith TM (1999), Considerations for use of the Barnett and Preisendorfer (1987) algorithm for canonical correlation analysis of climate variations. Journal of Climate 12:303-305.

Kuniholm, P. I., 1994. Long tree-ring chronologies for the Eastern Mediterranean. In Archaeometry '94: Proceedings of the 29th International Symposium on Archeometry, edited by Ş. Demirci, A. M. Özer, and G. D. Summers; pp. 401409. TUBITAK, Ankara.

Kuniholm, P. I., 2000. Dendrochronologically dated Ottoman monuments. In A Historical Archaeology of the Ottoman Empire: Breaking New Ground, edited by U. Baram, and L. Carroll; pp. 93-136. Kluwer Academic/Plenum, New York.

Kuniholm, P. I., and Striker, C. L., 1987. Dendrochronological investigations in the Aegean and neighboring regions, 1983-1986. Journal of Field Archaeology 14(4):385-398.

Kuniholm, P. I., B. Kromer, S. W. Manning, M. Newton, C. E. Latini, and M. J. Bruce, 1996. Anatolian tree rings and the absolute chronology of the Eastern Mediterranean, 2220-718 BC. Nature 381(6585):780-783.

Lev-Yadun, S., N. Liphschitz, Y. Waisel, 1981. Dendrochronological investigations in Israel: Pinus halepensis Mill.- the oldest living pines in Israel. LaYaaran 31(1-4): 1-8, 49-52.

Liphschitz, N., and Y. Waisel, 1967. Dendrochronological studies in Israel, Quercus boisseri of Mt. Meron region. La-Yaaran 17:78-91, 111-115. In Hebrew.

Mariotti, A., N. Zeng, and K.-M. Lau, 2002. Euro-Mediterranean rainfall and ENSO-a seasonally varying relationship. Geophysical Research Letters 29(12): doi:10.1029/2001GL014248.

Munaut, A. V., 1982. The Mediterranean area. In Climate from Tree Rings, edited by M. K. Hughes, M. P. Kelly, J. R. Pilcher, and V. C. La Marche; pp. 151154. Cambridge University Press, Cambridge.

Mutlu, H., N. Köse, N., Ü. Akkemik, D. Aral, A. Kaya, S. W. Manning, C. L. Pearson, and N. Dalfes, 2012. Environmental and climatic signals from stable isotopes in Anatolian tree rings, Turkey. Regional Environmental Change 12(3):559-570.

Parsapajouh, D., O. U. Bräker, and E. Schär, 1986. Étude dendroclimatologique du bois de Taxus baccata du nord de l'Iran. Schwizerische Zeitschrift für Forstwesen 137:853-868.

Pearson, C. L., C. B. Griggs, P. I. Kuniholm, P. W. Brewer, T. Wazny, and L. Canady, 2012. Dendroarchaeology of the mid-first millennium AD in Constantinople. Journal of Archaeological Science 39(11):3402-3414.

Peterson, T. C., and R. S. Vose, 1997. An overview of the Global Historical Climatology Network temperature database. Bulletin of the American Meteorological Society 78(12):2837-2849.

Pfister, C., R. Brázdil, and R. Glaser, 1999. Climatic variability in sixteenth-century Europe and its social dimension. Climatic Change 43:5-53.

Purgstall, B. J. V. H., 1983. Ottoman State History, Volumes 1-7, translated by Vecdi Bürün. Üçdal Publishing, Istanbul. In Turkish.

Shanan, L., M. Evenari, and N. H. Tadmor, 1967. Rainfall patterns in the central Negev Desert. Israel Exploration Journal 17(3):163-184.

Touchan, R., and M. K. Hughes, 1999. Dendrochronology in Jordan. Journal of Arid Environments 42(4):291-303.

Touchan, R., D. M. Meko, M. K. Hughes, 1999. A 396-year reconstruction of precipitation in Southern Jordan. Journal of the American Water Resources Association 35(1):49-59. 
Touchan, R., G. M. Garfin, D. M. Meko, G. Funkhouser, N. Erkan, M. K. Hughes, and B. S. Wallin, 2003. Preliminary reconstructions of spring precipitation in southwestern Turkey from tree-ring width. International Journal of Climatology 23(2):157-171.

Touchan, R., G. Funkhouser, M. K. Hughes, and N. Erkan, 2005a. Standardized precipitation indices reconstructed from Turkish tree-ring widths. Climatic Change 72(3):339-353.

Touchan, R., E. Xoplaki, G. Funkhouser, J. Luterbacher, M. K. Hughes, N. Erkan, Ü. Akkemik, and J. Stephan, 2005b. Dendroclimatology and large-scale circulation influences in the Eastern Mediterranean and Near East region. Climate Dynamics 25(1):75-98.

Touchan, R., Ü. Akkemik, M. K. Hughes, and N. Erkan, 2007. May-June precipitation of South-Western Anatolia, Turkey during the last 900 years from tree rings. Quaternary Research 68(2):196-202.
Touchan, R., K. J. Anchukaitis, D. M. Meko, S. Attalah, C. Baisan, and A. Aloui, 2008. The long term context for recent drought in northwestern Africa. Geophysical Research Letters 35:L13705, doi:10.1029/2008GL034264.

Touchan, R., K. J. Anchukaitis, D. M. Meko, M. Sabir, S. Attalah, and A. Aloui, 2011. Spatiotemporal drought variability in northwestern Africa over the last nine centuries. Climate Dynamics 37(1-2):237-252.

Touchan, R., K. J. Anchukaitis, V. V. Shishov, F. Sivrikaya, J. Attieh, M. Ketmen, J. Stephan, I. Mitsopoulos, A. Christou, and D. M. Meko, 2014. Spatial patterns of Eastern Mediterranean climate influence on tree growth. The Holocene 24(4):381-392.

Waisel, Y., and N. Liphschitz, 1968. Dendrochronological studies in Israel II. Juniperus phoenicea of North and Central Sinai. La-Yaaran 18:1-22, 63-67.

White, S., 2011. The Climate of Rebellion in the Early Modern Ottoman Empire. Cambridge University Press, Cambridge. 